pÿAbel and Dan (2 Sam 20:18 19) in Textual Criticism, Tradition History, and Archaeology

Kauhanen, Tuukka

2020

pÿKauhanen , T \& de Hulster , I J 2020 , ' Abel and Dan (2 Sam 20:18 19) in Textual Criticism, Tradition History, and Archaeology ' , Textus : annual of the Hebrew University Bible Project. , vol. 30 , no. 1 , pp. 7-27 . https://doi.org/10.1163/2589255X-bja10009

http://hdl.handle.net/10138/338150

https://doi.org/10.1163/2589255X-bja10009

cc_by_nc_nd

acceptedVersion

Downloaded from Helda, University of Helsinki institutional repository.

This is an electronic reprint of the original article.

This reprint may differ from the original in pagination and typographic detail.

Please cite the original version. 


\title{
Abel and Dan (2 Sam 20:18-19) in Textual Criticism, Tradition History, and Archaeology ${ }^{1}$
}

\begin{abstract}
The MT form of the saying of the wise woman in 2 Sam 20:18-19 presents multiple textcritical problems. Instead of "Let them inquire at Abel," the LXX refers to "Abel and Dan." The notion of the wise woman being "one of those who are peaceable and faithful in Israel" (NRSV) is grammatically difficult; the LXX reads differently: "what the faithful of Israel had established, had been abandoned."

This paper seeks to bring textual criticism into discussion with an archaeological analysis, including a tradition-historical angle on the story, by:

1. Re-examining the textual evidence, with due consideration of the Septuagint.

2. Considering the archaeological findings of Iron Age sites at Tel Abel and Tel Dan.

3. Examining the textual and iconographic implications of the motif "woman on the wall."

4. Evaluating the plausibility of the historical settings implied in the story in light of the textual and archaeological evidence.
\end{abstract}

\section{Keywords}

2 Sam 20:18-19 MT / 2 Kingdoms 20:18-19 LXX, interdisciplinary approaches, textual criticism, archaeology, tradition history, Abel-beth-maacah, Dan, wise woman, women on city walls.

\footnotetext{
${ }^{1}$ This article is based on our collaboration in the Centre of Excellence "Changes in Sacred Texts and Traditions" (CSTT), funded by the Academy of Finland, 2014-2019, led by Martti Nissinen.
} 


\section{$1 \quad$ Narrative Context}

The story of Absalom's revolt in 2 Sam 15-19 ends with victorious King David returning from the other side of the Jordan and heading towards Jerusalem (19:19). Before David reaches Jerusalem, a dispute arises between Judah and Israel about who has the biggest "portion in David" (19:43). The dispute leads to another revolt: "Sheba son of Bichri, a Benjaminite ... sounded the trumpet and cried out, 'We have no portion in David, no share in the son of Jesse! Everyone to your tents, O Israel!'” (20:1). Having arrived home, David immediately begins preparations and aptly summarizes the situation: "Now Sheba son of Bichri will do us more harm than Absalom." He commands Amasa, the former commander of Absalom's troops whom he promised to make commander instead of Joab, to gather troops for a new war (20:5; cf. 17:25, 19:14). The campaign starts slowly, and after a confusing set of events, the deposed Joab kills Amasa and takes the lead (20:6-10).

Meanwhile, Sheba has been gathering troops and has reached Abel-beth-maacah. Either he is unaware of being pursued or he believes he is able to defend himself in the city, because he takes no action and allows Joab to besiege Abel. When Joab's forces start to batter the walls, the following exchange takes place-according to the Masoretic Text (MT):

(20:16) Then a wise woman called from the city, "Listen! Listen! Tell Joab, ‘Come here, I want to speak to you."' (17) He came near her; and the woman said, "Are you Joab?" He answered, "I am." Then she said to him, "Listen to the words of your servant." He answered, "I am listening." (18) Then she said, "They used to say in the old days, 'Let them inquire at Abel'; and so they would settle a matter. (19) I am one of those who are peaceable and faithful in Israel; you seek to destroy a city that is a mother in Israel; why will you swallow up the heritage of the Lord?" (20) Joab answered, "Far be it from me, far be it, that I should swallow up or destroy! (21) That is not the case! But a man of the hill country of Ephraim, called Sheba son of Bichri, has lifted up his hand against King David; give him up alone, and I will withdraw from the city." The woman said to Joab, "His head shall be thrown over the wall to you." (22) Then the woman went to all the people with her wise plan. And they cut off the head of Sheba son of Bichri, and threw it out to Joab. So 
he blew the trumpet, and they dispersed from the city, and all went to their homes [tents], while Joab returned to Jerusalem to the king. (NRSV)

This ends the story of Sheba's revolt. It is followed by a short note about David's officials. The Succession Narrative is continued only in $1 \mathrm{Kgs} 1$, while the rest of 2 Samuel consists of "Miscellanies," stories and a psalm that appear to have no function in the broader narrative. $^{2}$

\section{Textual Evidence}

Throughout ch. 20, the MT contains signs of slight corruption or late revision. One of the more striking differences between the MT and the LXX can be seen in two verses of the wise woman's words: all the Greek witnesses present a considerably longer text than the MT. This is because they attest to a double translation of the very same Hebrew passage: “'When inquiring, they shall inquire in Abel,' and likewise if they had abandoned it. I am a peaceful one of the supports of Israel, ..." (NETS). Below the texts are arranged so that it is possible to see the MT, the putative original LXX translation, and the doublet side by side. The original LXX follows the forthcoming eclectic edition by Kauhanen. ${ }^{3}$

\begin{tabular}{|c|c|c|c|}
\hline & MT (BHS) & The original LXX & A secondary doublet \\
\hline \multirow[t]{5}{*}{18} & דַדבּּר יְדַבְּרְרוּ & 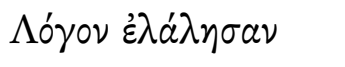 & \\
\hline & 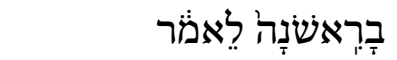 & 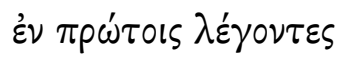 & \\
\hline & نָָׁאלל & 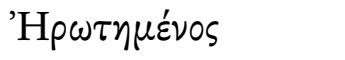 & $\varepsilon \dot{\varepsilon} \omega \tau \tilde{\omega} \nu \tau \varepsilon \varsigma$ \\
\hline & 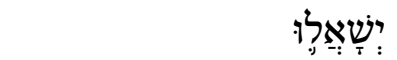 & $\eta \dot{\eta} \rho \tau \dot{\eta} \theta \eta$ & $\varepsilon \dot{\pi} \pi \varepsilon \omega \tau \dot{\eta} \sigma 0 v \sigma \iota \nu$ \\
\hline & 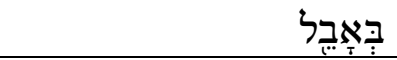 & $\dot{\varepsilon} \nu \tau \tilde{\eta}{ }^{\prime} A \beta \dot{\varepsilon} \lambda$ & 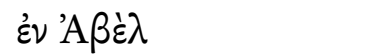 \\
\hline
\end{tabular}

\footnotetext{
2 See, e.g., Cynthia Edenburg, "2 Sam 21-24: Haphazard Miscellany or Deliberate Revision?" in Insights into Editing in the Hebrew Bible and the Ancient Near East, ed. Reinhard Müller and Juha Pakkala, CBET 84 (Leuven: Peeters, 2017), 189-222.

3 Tuukka Kauhanen; Septuaginta: Vetus Testamentum Graecum. Auctoritate Academiae Scientiarum Gottingensis editum. Band V, 2: Regnorum liber II (Samuelis II) (forthcoming). Rahlfs' edition includes the

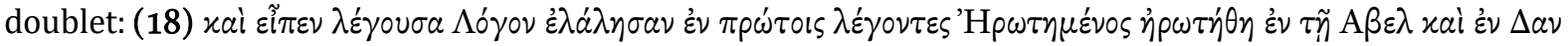

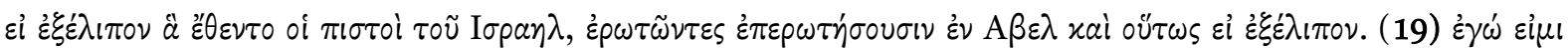

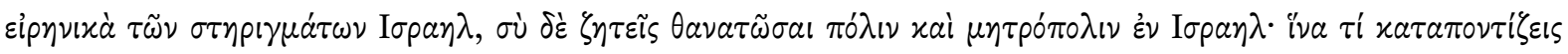
xinpovouiav xupiov;
} 


\begin{tabular}{|c|c|c|c|}
\hline & 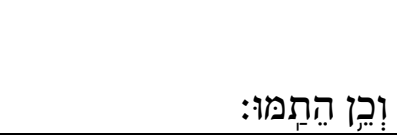 & 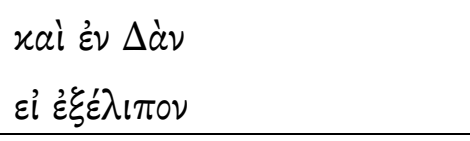 & 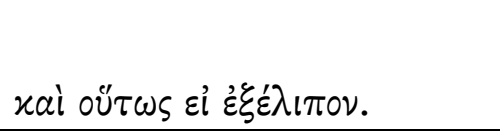 \\
\hline 19 & 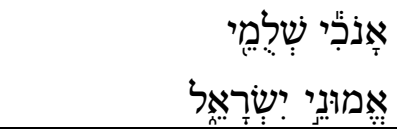 & 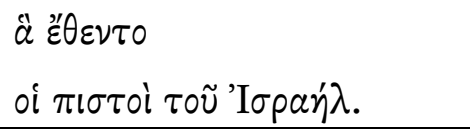 & 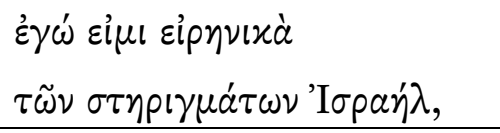 \\
\hline 18 & $\begin{array}{l}\text { They used to say } \\
\text { in the old days, } \\
\text { "Let them inquire at } \\
\text { Abel"; } \\
\text { and so they would } \\
\text { settle a matter. }\end{array}$ & $\begin{array}{l}\text { They spoke a saying } \\
\text { in former [days], saying, } \\
\text { "When inquired of, one } \\
\text { was inquired of in Abel } \\
\text { and in Dan, } \\
\text { whether }\end{array}$ & $\begin{array}{l}\text { "When inquiring, they shall } \\
\text { inquire in Abel," } \\
\text { and likewise if they had } \\
\text { abandoned it. }\end{array}$ \\
\hline 19 & $\begin{array}{l}\text { I am (one of) the } \\
\text { peaceable of the } \\
\text { faithful } \\
\text { in Israel; } \\
\text { (NRSV modified) }\end{array}$ & $\begin{array}{l}\text { what the faithful } \\
\text { of Israel had established, } \\
\text { had been abandoned." } \\
\text { (our trans.) }\end{array}$ & $\begin{array}{l}\text { I am a peaceful one } \\
\text { of the supports } \\
\text { of Israel, ... } \\
\text { (NETS) }\end{array}$ \\
\hline
\end{tabular}

Before comparing the Hebrew and Greek texts, a brief discussion of the most important Greek variants is in order. The latter part of 2 Samuel (10-24) contains one of the socalled kaige sections in Samuel-Kings. ${ }^{4}$ In these sections, B and the majority of the manuscripts attest to the Hebraizing kaige revision. The Lucianic (Antiochene) text, represented by the manuscript group $L$, is mostly free from the influence of the kaige revision, but contains a much later revision of another kind. The original translation has to be reconstructed by comparing the readings of the manuscripts and contrasting them with the translational choices in the non-kaige section of Samuel (1 Sam 1 - 2 Sam 9).

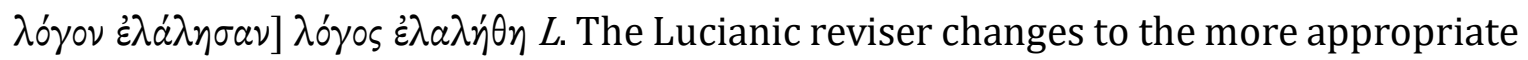

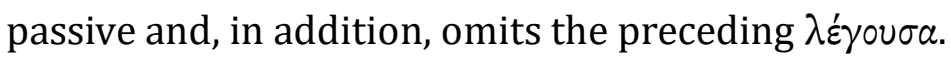

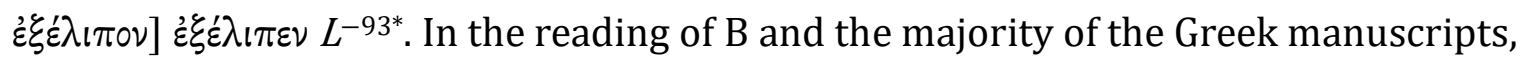
a $\varepsilon^{\prime} \theta \varepsilon \nu \tau o$ can be interpreted as the object ("if they had abandoned what had been established") or as the subject ("if what had been established were to cease"). In Septuagint

\footnotetext{
${ }^{4}$ The opinions vary on the exact extent of the section. Recently, 2 Sam 10:6 has been suggested as the starting point by Raimund Wirth, Die Septuaginta der Samuelbücher: Untersucht unter Einbeziehung ihrer Rezensionen, De Septuaginta Investigationes 7 (Göttingen: Vandenhoeck \& Ruprecht, 2016), 199201.
} 
Greek, a plural predicate for a neuter plural subject is tolerated, ${ }^{5}$ and the verb $\varepsilon \dot{x} \lambda \varepsilon^{\prime} i \pi \omega$ can be used intransitively; thus, it seems more natural to take $\stackrel{\alpha}{\varepsilon}{ }^{\prime} \theta \varepsilon v \tau o$ as the subject rather than an object. ${ }^{6}$ The Lucianic reviser tends to change the predicates for neuter plural subjects to singular. ${ }^{7}$

The doublet in v. 18 (right-most column above), "When inquiring, they shall inquire in Abel,' and likewise if they had abandoned it. I am a peaceful one of the supports of Israel, ..." (NETS), corresponds more faithfully to the MT: it retains the plural form of the

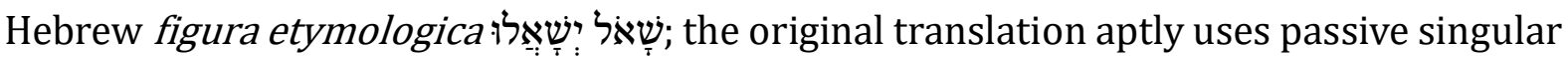

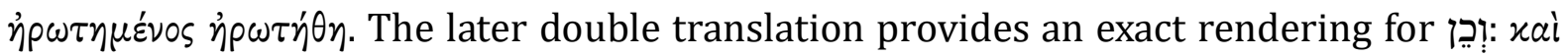
oú $\tau \omega \varsigma$, "and likewise." For the first words of v. 19, it provides a translation closely following the MT:

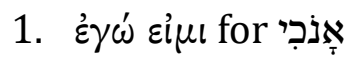

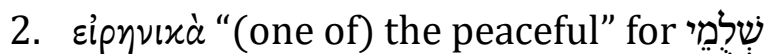

3. The word $\sigma \tau \eta^{\prime} \rho \imath \mu \alpha$, "support, foundation" is found nowhere else in Greek Samuel, in which Hebrew words featuring the root אמן are translated exclusively

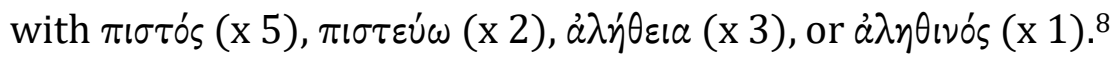

\footnotetext{
${ }^{5}$ Henry St. John Thackeray, A Grammar of the Old Testament in Greek according to the Septuagint (Cambridge: University Press, 1909), 23: "Neuter plurals may take either a singular or plural verb."

${ }^{6}$ This is reflected in our translation above. NETS interprets the syntax differently and ends the quotation after "Abel": "A saying they spoke at first, saying, 'When inquired of, one was inquired of in Abel,' and in Dan if they had abandoned what had established the faithful of Israel." While the punctuation in our translation does not reflect it, we acknowledge the possibility of dividing the sentence to make a juxtaposition between a right answer in Abel and a heretical one in Dan: "When inquired of, one was inquired of in Abel; and in Dan (only) if what the faithful of Israel had established had (already) been abandoned."

${ }^{7}$ Sebastian P. Brock, Recensions of the Septuaginta Version of 1 Samuel, Quaderni di Henoch 9 (Turin: Silvio Zamorani, 1996), 248-49.

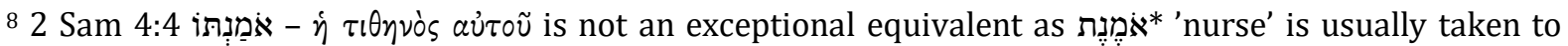
represent another, homonymous root. Elsewhere in Samuel-Kings $\sigma \tau \dot{\eta} \rho \imath \mu \mu \alpha$ is found only in 2 Kgs 25:11 corresponding to המון in the MT. The rendering may reflect an etymological derivation from אמן and it likely

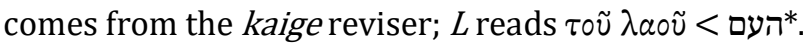




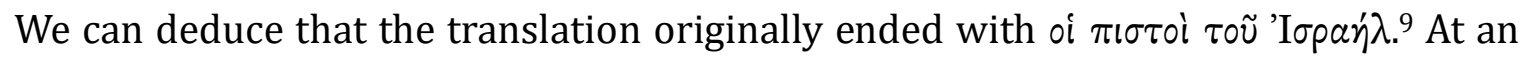
early stage, someone added a double translation corresponding to what can now be found in the MT, but with small details that set it apart from the translational profile of the original translator. Usually such doublets are added before the old translation but for some reason here it was appended after it. In the forthcoming eclectic edition of the Greek 2 Samuel, the doublet will be printed in the main text in square brackets to signal that it does not come from the original translator though it is part of the text transmitted in all the extant witnesses:

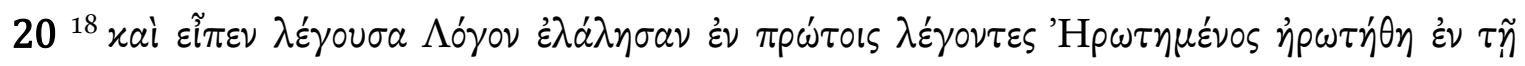

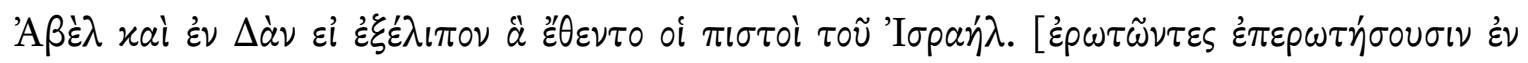

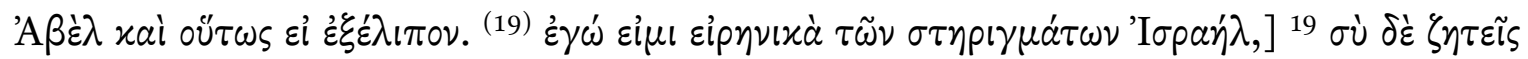

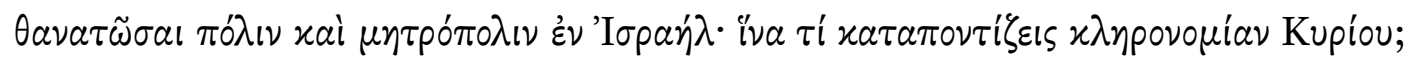

Another striking issue is that the original Greek translation is semantically quite different from the MT. The following presents a tentative retroversion of the Hebrew base text. $^{10}$

\begin{tabular}{|c|c|c|c|}
\hline & MT (BHS) & $\begin{array}{l}\text { Barthélemy, } \\
\text { McCarter }\end{array}$ & LXX \\
\hline \multirow[t]{4}{*}{18} & 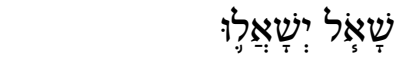 & שאל ישאלו & 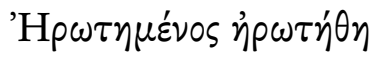 \\
\hline & בְּאָבֶל & באבל & $\dot{\varepsilon} \nu \tau \tilde{\eta}{ }^{\prime} A \beta \dot{\varepsilon} \lambda$ \\
\hline & זוכֵן & 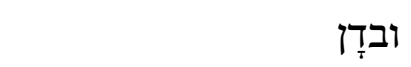 & xal ह่v $\Delta \dot{\alpha} \nu$ \\
\hline & הַתַפוּ: : & 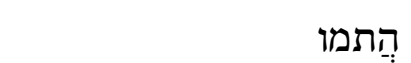 & 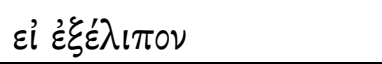 \\
\hline
\end{tabular}

\footnotetext{
${ }^{9}$ This is accepted by many commentators, esp. Julius Wellhausen, Der Text der Bücher Samuelis (Göttingen: Vandenhoeck \& Ruprecht, 1871), 297; Dominique Barthélemy, Critique textuelle de l'Ancien Testament 1: Josué, Juges, Ruth, Samuel, Rois, Chroniques, Esdras, Néhémie, Esther, OBO 50 (Göttingen: Vandenhoeck \& Ruprecht, 1982), 297-9; P. Kyle McCarter, Jr., II Samuel, AB 9 (Garden City, NY: Doubleday, 1984), 428-29. 10 Such a reading was already anticipated by Julius Wellhausen; this word-for-word reconstruction was presented by Dominique Barthélemy and adopted by P. Kyle McCarter. Dominique Barthélemy, Les devanciers d'Aquila: Première publication intégrale du texte des fragments du Dodécaprophéton, VTSup 10 (Leiden: Brill, 1963), 72, 122-3; McCarter, II Samuel, 426, 428-9.
} 


\begin{tabular}{|c|c|c|c|}
\hline 19 & 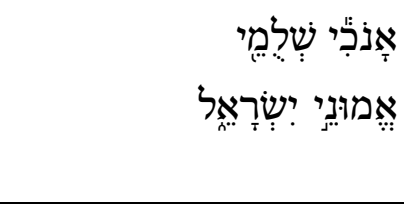 & אמוני ישראל שָׁמוּ & 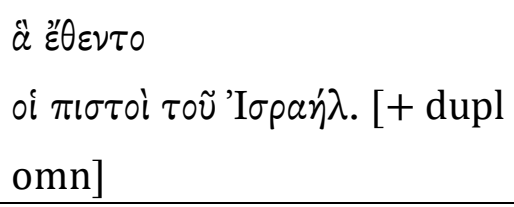 \\
\hline 18 & $\begin{array}{l}\text { "They used to say } \\
\text { in the old days, } \\
\text { 'Let them inquire at } \\
\text { Abel'; } \\
\text { and so they would } \\
\text { settle a matter. }\end{array}$ & & $\begin{array}{l}\text { They spoke a saying } \\
\text { in former [days], saying, } \\
\text { "When inquired of, one was } \\
\text { inquired of in Abel } \\
\text { and in Dan, } \\
\text { whether }\end{array}$ \\
\hline 19 & $\begin{array}{l}\text { I am (one of) the } \\
\text { peaceable of the } \\
\text { faithful } \\
\text { in Israel; } \\
\text { (NRSV modified) }\end{array}$ & & $\begin{array}{l}\text { what the faithful } \\
\text { of Israel had established, } \\
\text { had been abandoned." } \\
\text { (our trans.) }\end{array}$ \\
\hline
\end{tabular}

The difference between "and so" (וכן) and "and in Dan" (ובדן) can be easily explained by a graphical error from one to another: a bet-kaf confusion and a quasi-dittography or haplography of dalet and final nun. The MT vocalization makes the last word a hiphil perfect (התתמו). However, it has no object, while elsewhere in the Hebrew Bible hiphil תמם usually has one (with object: 2 Kgs 22:4; Isa 33:1; Ezek 22:15, 24:10; Job 22:3; no object: Dan 8:23). ${ }^{11}$ One would rather expect qal for the meaning "it was settled." In the tentative base text of the Septuagint, he in the last word of v. 18 (התמו) should be pointed as an interrogative particle. That makes the verbal form qal, and the particle suggests the sentence continues: "Let them inquire ... whether it has been settled (or: "carried out"), that...

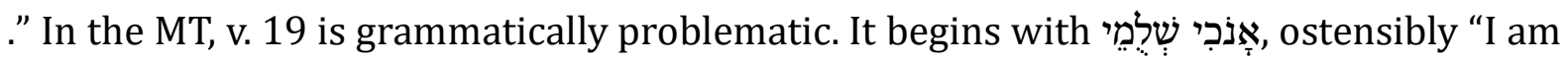

\footnotetext{
${ }^{11}$ It must be noted that in instances such as this, grammars and lexica tend to be highly problematic. Usually, they accept the MT at face value and explain the unusual forms as singular instances of an acceptable phenomenon. For instance, The Dictionary of Classical Hebrew: Vol. 8: Šin-Taw, ed. David J. Clines (Sheffield: Sheffield Phoenix Press, 2011), 648, takes 2 Sam 20:18 as evidence for the meaning "settle a matter" for תמם. That grammars and lexica recognize a usage on the basis of very few or singular instances in the MT cannot be used as an argument against corruption. Of course, an unusual grammatical form or turn of phrase is not, as such, an argument for it resulting from corruption.
} 
of the peaceable." One would rather expect אנכי אחת משלמי*, "I am one of...," (see, e.g., 1 Sam $1: 1 ; 9: 3)$. In addition, the construct chain "the peaceable of the faithful of Israel" is unusual. A graphical confusion between אנכי שלמי and אשר שמו would suggest a somewhat damaged surface or otherwise poor condition, but there are enough letters of the same (alef, šin, mem) or similar (kaf-reš, yod-waw) shape to suggest one on the basis of the other.

The considerations above strongly suggest that the variation between the MT and the proposed Vorlage of the LXX is brought about by corruption. This being the case, preference should be given to the reading most plausible by internal considerations. Indeed, many commentators in the past 150 years have considered the MT corrupt or, at least, "troubled."12 McCarter accepts the reconstructed base text as closest to the original Hebrew. ${ }^{13}$ Barthélemy, however, defends the MT: while the reading is difficult, it is coherent with acceptable Hebrew usage, and to introduce Dan in the reading would be unnecessary for the proverb. While somewhat abrupt, the sentence break "they would settle a matter. I am one of..." is plausible as the juxtaposition "I am one of the peaceable ... you [= Joab] seek to destroy" functions well rhetorically. ${ }^{14}$ Curiously, the most extensive analysis of the problem so far, published by Robert P. Gordon in Vetus Testamentum in 1993, leaves the question open:

[T] he MT is intelligible, which means that emendation to agree with the LXX's alternative reading is a questionable solution to the "problem" ... In our present state of knowledge we can but take note of both readings, allowing at the same time for the possibility that the absence of Dan from the MT has a polemical

\footnotetext{
12 Karl Budde, Die Bücher Samuel, Kurzer Hand-Commentar zum Alten Testament 8 (Tübingen: Mohr, 1902), 296, is exemplary: "Der Text des Capitels hat ungewöhnlich stark gelitten."

13 Similarly Wellhausen, Der Text der Bücher Samuelis, 297; Henry Preserved Smith, A Critical and Exegetical Commentary on the Books of Samuel, ICC (Edinburgh: T\&T Clark, 1977), 371-2.

14 Barthélemy, Critique textuelle, 297-99; see also Dominique Barthélemy, "La qualité du Texte Massorétique de Samuel," in The Hebrew and Greek Texts of Samuel, Proceedings of the International Organization for Septuagint and Cognate Studies and the Society of Biblical Literature, Pseudepigrapha Seminar (Atlanta: Society of Biblical Literature, 1980), 1-44.
} 
explanation. And if polemic were involved, the superiority of the assumed Greek Vorlage would scarcely be in doubt. ${ }^{15}$

Against Gordon, we maintain that the intelligibility of the MT does not justify putting "problem" in quotation marks: the problem is the textual variation and a solution to that must be sought for. We strongly disagree with the suggestion that we should only "take note of both readings." As the difference in all likelihood goes back to corruption, and not polemics, only one of the two-or three-readings can be original.

Still perhaps more curious is a recent suggestion by Nadav Na'aman. He argues that the story of Sheba's revolt in 2 Sam 20 is composed of two parts. 2 Sam 20:1-13 is written as a sequel to Absalom's revolt (2 Sam 15-19) by the author of the Succession Narrative (2 Sam 9-20; 1 Kgs 1-2). 2 Sam 20:14-22a preserves an earlier story, written in the Kingdom of Israel in the 8th century BCE, and contains a historical nucleus. ${ }^{16}$ For Na'aman, a key notion in the early story is the juxtaposition of Abel-beth-maacah and Dan in the Septuagint version of 20:18-19. The essence of the saying would be that, when asking for an oracle in both Abel and Dan, one would get the definitive reply at Abel. Na'aman translates the long Greek reading thus: "[M]ake (prophetic) inquiry in Abel and in Dan whether they had omitted what the faithful of Israel established. (Then) they made (prophetic) inquiry at Abel, and so they settled it."17 He concludes that

[T] he LXX makes perfect sense as it suggests that the query was put forward in two neighbouring towns, Dan and Abel, but the definitive response was received at Abel. Hence, I doubt whether the LXX reflects a double translation. With all due caution, I tend to support the priority of the LXX, and assume that the first part of the original Hebrew text was omitted in the MT due to homoioteleuton. ${ }^{18}$

We noted above that:

\footnotetext{
15 Robert P. Gordon, “The Variable Wisdom of Abel: The MT and Versions at 2 Samuel XX 18-19," VT 43 (1993): 226.

16 Nadav Na'aman, “Source and Composition in the Story of Sheba's Revolt (2 Samuel 20)," RB 125 (2018): 340-52.

17 Na'aman, "Source and Composition," 347; Hebrew portions are omitted from the translation.

18 Na'aman, “Source and Composition," 347-48.
} 
- Some features of the wise woman's words in the doublet in the LXX manuscripts do not fit the usual usage of the original translator well.

- The MT and the back-translation of the former part of the LXX can be seen as transcriptional variants of each other.

- As it stands, the MT is possible grammatically, but the more problematic reading semantically, given: 1. the intransitive hiphil התחמה 2. 2. the deficient form for the

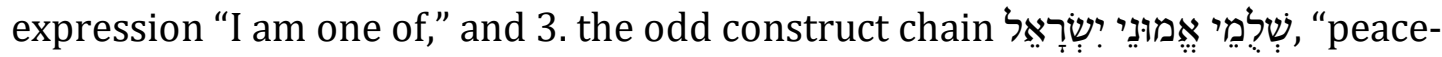
able of the faithful of Israel."

For these reasons, we find it methodologically impossible to give any further source-critical, narrative-critical, or historical thought to the Greek double reading "'make (prophetic) inquiry in Abel and in Dan whether they had omitted what the faithful of Israel established'. (Then) they made (prophetic) inquiry at Abel, and so they settled it." The double reading was brought about by a Hebraizing revision at an early stage of transmission in the Septuagint, probably in the first century BCE, and it never existed in a Hebrew text. It tells nothing about the composition or redactions of Samuel, the historical surroundings of Sheba's revolt, or Iron Age Abel or Dan.

However, $\mathrm{Na}$ 'aman must be commended for a fresh combination of textual, narrative, and source criticism with archaeological and historical considerations. His article prompted us to consider the historical plausibility of the implied setting of the readings "Abel" in the MT and "Abel and Dan" in the LXX in light of the material evidence. The primary variation between the MT and the LXX is, indeed, the reading "and Dan" in the LXX; the evaluation of the other readings is dependent on that. Of course, considering historical plausibility does not imply that we thought a priori that the story of Sheba's revolt and the wise woman of Abel had a historical nucleus. However, historical plausibility may help us assess what the authors or redactors of a historical narrative produced.

An investigation on the historical plausibility of the "Abel" or "Abel and Dan" reading must take a number of considerations into account. Beyond the question of a possible historical nucleus, we first of all need to take into consideration possible other scenarios for the origins of the text-for example, emerging from or partly being influenced by literary or iconographic motifs. We would also like to consider in which periods the reading 
mentioning both "Abel and Dan" would be best understood. It is our aim to map the interrelations of the necessary methodological considerations elsewhere. ${ }^{19}$

Texts were written by humans at some place, at some time in history. These people had their own cultural heritage, including collective memories and motifs. Therefore, in order to better understand the possible origins of 2 Sam 20, we will concentrate on the most important considerations related to this historical question (especially within the chronological framework of late Iron I and Iron IIa, i.e., 10th to 9th centuries BCE): topography, material culture, the existence of an oracle and women on city walls as a motif. We need to be aware of the fact that the material-cultural remains, through which we reconstruct historical circumstances, are only partial: not everything survives the ravages of time and among what survives, not everything has been excavated. Even what has been excavated is subject to interpretation and re-evaluation.

\section{Abel and Dan from an Archaeological Perspective}

\subsection{Topography and Historical Reconstruction}

Most scholars agree that Tell Abil el-Qameh, just south of present-day Metula (the most northern town in the State of Israel, located on the border with Lebanon) is to be identified with Abel-beth-maacah and that Tell el-Qadi (6-7 km slightly to the southeast of Abel) contains the remains of ancient Dan; it is named "Tel Dan" on Israeli maps. ${ }^{20}$ The

\footnotetext{
${ }^{19}$ Izaak J. de Hulster \& Tuukka Kauhanen, “Source Criticism Meets Archaeology: An Interdisciplinary
} Approach to Abel (and Dan?) in 2 Samuel 20:18-19," forthcoming in an interdisciplinary volume with contributions by members of the Academy of Finland Centre of Excellence "Changes in Sacred Texts and Traditions (CSTT)" (2014-2019), edited by Martti H. Nissinen and Jutta M. Jokiranta.

20 Identifications/surveys of Tell Abil-el-Qameh were carried out during the 19th century by Victor Guerrin and Edward Robinson, in the 1960s by Yehudah Dayan, in 1973 by William Dever, and in 1990-1992 by Idan Shaked and Yosef Stefansky. After a survey in 2012, an excavation began in 2013, directed by Nava Panitz-Cohen, Naama Yahalom-Mack and Robert Mullins. Only Edward Lipiński and Zvi Ma'oz have suggested the identification of Tell el-Qadi with Abel-beth-maacah; Edward Lipiński, The Aramaeans: Their Ancient History, Culture, Religion, OLA 100 (Leuven: Peeters, 2000), 372-73; Zvi U. Ma'oz, Dan is Baniyas: Teldan is Abel Beth Ma'acha, Archaostyle Scientific Research Series 2 (Qazrin: Archaostyle, 2006). Among the arguments for identifying Tell Abil-el-Qameh as Abel-beth-maacah is the word "Abel" preserved as "Abil" in the name of the village Abil-el-Qameh that existed until halfway through the 20th century. On Tel Dan, see Avraham Biran, "Dan," in The New Encyclopedia of Archaeological Excavations in the Holy Land, 
archaeological findings suggest that both Abel and Dan were fortified cities during the Bronze Age.

For Dan, the material evidence suggests a degree of discontinuity from the Late Bronze Age to the Iron Age I. From a historical point of view, this might be linked with the withdrawal of the Egyptians from the area in $1140 \mathrm{BCE} ;{ }^{21}$ however, evidence for an active Egyptian presence at Dan in the Late Bronze Age is contested. ${ }^{22}$ During the whole of the Iron Age I (Strata VI, V and IVB) no fortifications can be observed; either there were none or none have been preserved. ${ }^{23}$ In combination with other factors, such as a drought, the archaeological record testifies to several destructions, possibly earthquakes, during this period. Although Dan was inhabited during the entire Iron I, its population decreased at the turn from Iron I to Iron IIa, but experienced a large-scale revival in the second half of the 9th century (Stratum IVA). ${ }^{24}$ Stratum III shows the remains of massive fortifications,

ed. Ephraim Stern (Jerusalem: Israel Exploration Society \& Carta, 1993-2008), 1:323-32; idem, Biblical Dan (Jerusalem: Israel Exploration Society, 1994); idem, "Dan: An Update to Vol. I, pp. 323-332," in New Encyclopedia of Archaeological Excavations in the Holy Land, 5:1686-89; David Ilan, "Dan," in The Oxford Encyclopedia of Archaeology in the Near East, ed. Eric M. Meyers (New York: Oxford University Press, 1997), 2:107-12; idem, "Dan," in The Oxford Encyclopedia of the Bible and Archaeology, ed. Daniel M. Master (Oxford: Oxford University Press, 2013), 1:245-54; and see the following footnotes.

${ }^{21}$ So, among others, David Ilan, one of the co-authors of David Kaniewski et al., "Supplementary Materials for Climate Change and Water Management in the Biblical City of Dan," Science Advances 3 (2017), table S2.

${ }^{22}$ Cf. Mario A.S. Martin and Rachel Ben-Dov, "Egyptian and Egyptian-style Pottery at Tel Dan,” AeL 17 (2007): 191-203; see also the discussion of Egyptian artefacts discussed in Andrew R. Davis, Tel Dan in Its Northern Cultic Context, ABS 20 (Atlanta: Society of Biblical Literature, 2013), 27-28; Merja Alanne, "Tel Dan - Biblical Dan: An Archaeological and Biblical Study of the City of Dan from the Iron Age II to the Hellenistic Period" (PhD diss., University of Helsinki, 2017), 57.

${ }^{23}$ Cf. David Ilan, "Household Gleanings from Iron I Tel Dan," in his Household Archaeology in Ancient Israel and Beyond, CHANE 150 (Leiden: Brill, 2011), 133-54.

${ }^{24}$ Eran Arie has an "occupational gap or insignificant settlement" between Iron Ib and Iron IIb, ca. 980-830 (high chronology) or 950-800 (low chronology); "Reconsidering the Iron Age II Strata at Tel Dan: Archaeological and Historical Implications," TA 35 (2008): 6-64. High and low chronology is, among other things, an issue of how the archaeological evidence can be related to absolute dating. Although most scholars follow Arie's hypothesis, the idea of a decrease and decline during most of Iron IIa at Dan should be evaluated in light of the proper publication and interpretation of the archaeological evidence that is still in process. 
a large sacred precinct, and a densely populated city. ${ }^{25}$ Presently, the material of Tel Dan is undergoing re-evaluation and awaiting final reports. ${ }^{26}$

In contrast, the results of the ongoing excavation at Tel Abel-beth-maacah seem to imply that there was not only continuity in settlement from the Late Bronze Age to the Iron Age but that Abel was flourishing. Abel was fortified during the Bronze Age and perhaps into the early Iron Age I. However, during the Iron Age I, pits were dug into the tower and walls (see the evidence in Area F, the southern edge of the mound). ${ }^{27}$ Therefore, we must conclude that the lower city did not have an effective fortification system by the end of the Iron Age I. It is hard to say anything conclusive about the upper city, as the presence of a few meters of rubble and two Israeli military bunkers complicate excavation; nevertheless, the most recent finds in Area B (located on the eastern slope of the upper mound, close to the summit) revealed part of a massive casemate building, dated to the late 10 th and 9 th centuries, that appears to have been a citadel. ${ }^{28}$

These observations concerning Tel Dan, together with the destruction of the nearby cities of Hazor to the south and Kumidi to the north at the end of the Late Bronze Age, suggest that Abel grew in importance at the turn of the Bronze Age to the Iron Age. Abel

25 David Kaniewski et al., "Climate Change and Water Management in the Biblical City of Dan," Science Advances 3 (2017), esp. figure 3B (and see supplementary materials, esp. table S2, in Kaniewski et al., "Supplementary Materials"); cf. Alanne, "Tel Dan," 47.

26 Initial publications by Avraham Biran, e.g., Biblical Dan; Biran's results are revised and reinterpreted, partly in light of more recent excavations: Arie, "Reconsidering the Iron Age II Strata at Tel Dan"; Yifat Thareani, "Enemy at the Gates? The Archaeological Visibility of the Aramaeans at Dan," in In Search for Aram and Israel: Politics, Culture, and Identity, ed. Omer Sergi, Manfred Oeming, and Izaak J. de Hulster, Oriental Religions in Antiquity 20 (Tübingen: Mohr Siebeck, 2016), 169-97; and Alanne, “Tel Dan.” David Ilan's Dan IV: The Early Iron Age Levels, Annual of the Nelson Glueck School of Biblical Archaeology 12 (Jerusalem: Hebrew Union College, 2019), was not available for the present research and was still forthcoming at the time of writing.

27 Nava Panitz-Cohen, Robert A. Mullins and Ruhama Bonfil, "Second Preliminary Report of the Excavations at Tell Abil el Qameh (Abel Beth Maacah)," Strata: Bulletin of the Anglo-Israel Archaeological Society 33 (2015): 35-59, esp. 44-47.

${ }^{28}$ Naama Yahalom-Mack, Nava Panitz-Cohen and Robert Mullins, "From a Fortified Canaanite City-State to a 'City and a Mother in Israel': Five Seasons of Excavation at Tel Abel Beth Maacah," Near Eastern Archaeology 81 (2018): 145-56, esp. 152-55. 
was likely the most prominent city in the region during the Iron Age I. ${ }^{29}$ Abel has at least two major destructions in Iron I (apparently to equal the destructions at Dan in Strata V and IVB). After the destruction at the end of Iron I (Stratum A2), the city was soon rebuilt and has been shown to be a well-settled urban centre. At the end of Iron IIa, apparently sometimes in the late 9th century BCE or at the latest, the very beginning of the 8th century, occupation at Abel-beth-maacah ceased, as no clear Iron IIb occupation that can be dated to the 8th century, nor any traces of the Assyrian destruction, were identified in the excavations to date. Thus, there is evidence for intense occupation in the late 10th and 9th centuries, but after that in Iron IIb (8th century) Abel seems to have been abandoned. This contrasts with Dan, where Iron Age IIb remains were excavated and studied in detail, revealing a significant rise in material culture. ${ }^{30}$

Although the archaeological data from Abel-beth-maacah is still being collected and only allow for drawing preliminary conclusions, nevertheless, we try to visualize the present stage of research in the following chart, based on the reports ${ }^{31}$ and observations in the field that are in the process of interpretation. ${ }^{32}$ The "rise and fall" of city, for instance, depends on numerous factors (and how they are weighed), such as population, fortification, relative importance in the region, trade contacts, industry, prosperity, etc., not to mention catastrophes such as military invasions or earthquakes.

${ }^{29}$ E.g., Panitz-Cohen, Mullins and Bonfil, "Second Preliminary Report," esp. 56; and more recently, YahalomMack, Panitz-Cohen and Mullins, "From a Fortified Canaanite City-State"; see further references at http://abel-beth-maacah.org/index.php/publications. Note that in our text above we include part of the Iron Age IIa, given the traditional start of this period at about 1000 BCE; however, for instance, David Ilan (excavator of Iron Age I at Tel Dan) dates the transition from Iron Age I to Iron Age II to about 950 BCE or even 900 BCE; moreover, the staff of the Abel-beth-maacah excavation prefers, archaeologically speaking, a date around $950 \mathrm{BCE}$.

30 For the Neo-Babylonian period there is no evidence of occupation at Tel Dan; during the Achaemenid period activity seems to have concentrated around the cult precinct (Area T) and likewise during the Hellenistic period, for which there are indications of light occupation.

31 Esp. Kaniewski et al., "Climate Change"; Panitz-Cohen, Mullins and Bonfil, "Second Preliminary Report"; and Yahalom-Mack, Panitz-Cohen and Mullins, "From a Fortified Canaanite City-State."

32 We would like to thank here Naama Yahalom-Mack, Robert Mullins and especially Nava Panitz-Cohen for our discussions and their clarifications in light of the most recent assessments of the archaeological data, in particular for Abel-beth-maacah (January 2020). We also thank David Ilan for our exchange on the history of Dan. We are, of course, solely responsible for what is written here. 


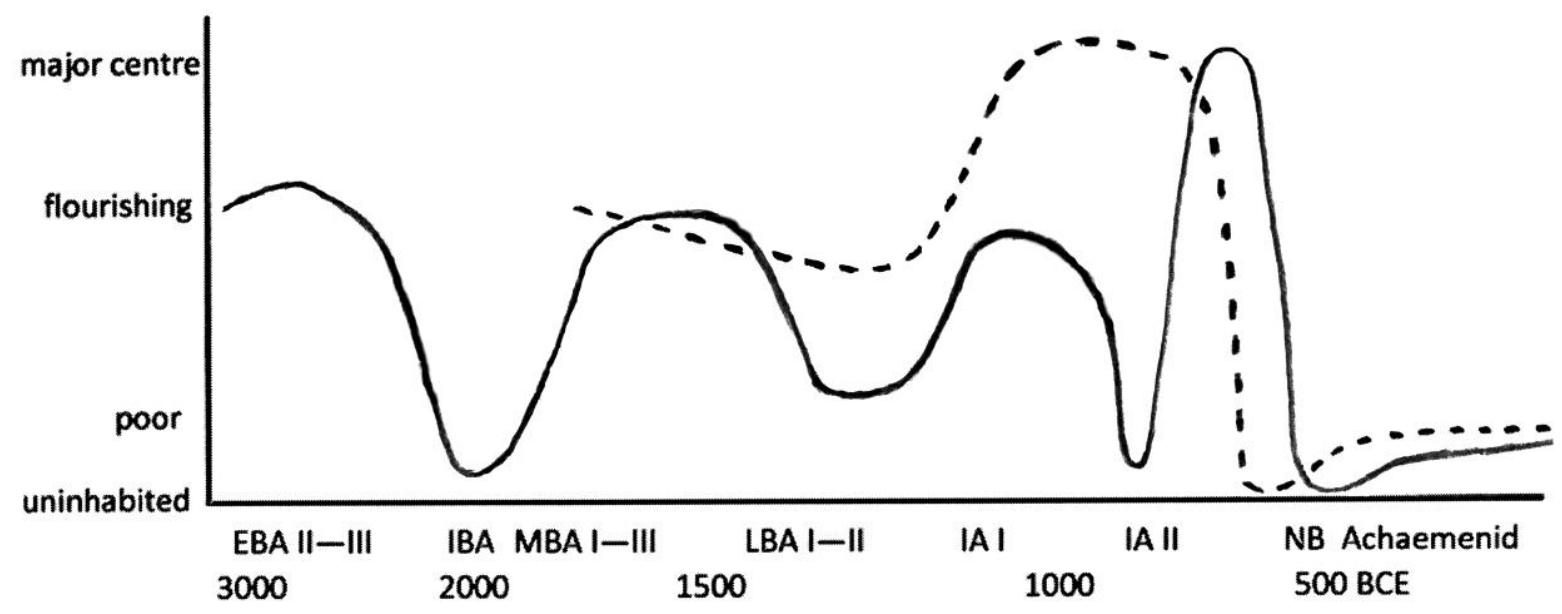

Chart 1. Sketch of the development of Dan (continuous line) and Abel-bethmaacah (dashed line). The dashed line starts in MBA II, as for the periods before we have no data yet. The scale does not allow to show catastrophes from which a city quickly recovered. EBA: Early Bronze Age; IBA: Intermediate Bronze Age; LBA: Late Bronze Age; IA: Iron Age; NB and Achaemenid: Neo-Babylonian and Achaemenid periods.

The narrative setting of 2 Sam 20 is at the end of the Iron Age I or rather early in the Iron Age IIa. ${ }^{33}$ Given Abel's status as an urban centre, Sheba might have had good reasons to go to Abel. The narrative of Sheba's revolt mentions Joab's siege (v. 15) and the exchange between Joab and the woman "calling from the city." These elements presuppose walls. As noted above, by the end of the Iron Age I, the city walls of Abel were put out of use by digging pits and silos into them. Area B near the summit of the tell contains a large casemate-like citadel structure (dated to the Iron Age IIa) that apparently served a role in the upper city's fortifications in the Iron Age IIa. Possibly, Sheba and the wise woman were in the upper city. From a different angle, one could argue that if there was a fortified place to withdraw or establish a seat of residence, Abel would have been the most likely place in the Galilee. From a historical perspective, one needs to add that the material culture of Palestine does not testify to siege warfare for this period. ${ }^{34}$

\footnotetext{
33 Cf. Nava Panitz-Cohen and Naama Yahalom-Mack, "The Wise Woman of Abel Beth Maacah," BAR 45 (2019): 33 .

${ }^{34}$ Siege warfare was introduced there only in the second half of the 9th century (if it was part of Hazael's conquest of Gath) or with the Assyrian conquest by the end of the 8th century. See Aren M. Maeir and Shira
} 


\subsection{Material Culture: A Perspective on Cultural and Political Affiliation}

The woman speaks about "a city that is a mother in Israel" (NRSV). If the woman used the word "Israel" at all, 35 there is no consensus on what it would have meant at this time. Moreover, there is no material culture that can be linked with a possible "Israel"-no "pots" to prove the existence of a specific "people." ${ }^{36}$ Nevertheless, we briefly address the

Gur-Arieh, "Comparative Aspects of the Aramean Siege System at Tell es-Sāfi/Gath," in The Fire Signals of Lachish: Studies in the Archaeology and History of Israel in the Late Bronze Age, Iron Age and Persian Period in Honor of David Ussishkin, ed. Israel Finkelstein and Nadav Na'aman (Winona Lake: Eisenbrauns, 2011), 227-44 (esp. 229). Cf. Omer Sergi, "The United Monarchy and the Kingdom of Jeroboam II in the Story of Absalom and Sheba's Revolts (2 Samuel 15-20)," HeBAI6 (2017): 340. Note that Joab might have attacked the wall of the upper city and a later redactor of the story phrased this in terms of siege warfare, unaware of adding an anachronism.

35 The first evidence for the name "Israel" as gentilicum is its mention at Merenptah's victory stele dated to 1208 BCE, now in the Cairo Museum (JE 31408); as a personal name it is much older; cf. Izaak J. de Hulster, “Das Berliner Steinfragment ÄM 21687 - die älteste Bezeugung der Volksbezeichnung 'Israel'?," Göttinger Miszellen: Beiträge zur ägyptologischen Diskussion 255 (2018): 67-80, esp. 67. The meaning of "Israel," marked by a hieroglyph as a gentilicum in JE 31408, is not clear. During Iron Age I, the name was possibly related to people living in the Galilee; cf. William W. Hallo and K. Lawson Younger, Jr., eds., Context of Scripture (Leiden: Brill, 2003), 2:40-41. Koert van Bekkum, however, cautions that one cannot be more specific than "Canaan," the territory of the Ramesside province of Asia; From Conquest to Coexistence: Ideology and Antiquarian Intent in the Historiography of Israel's Settlement in Canaan, CHANE 45 (Leiden: Brill, 2011), 204-29, 564-72. The next two occurrences of "Israel" in reference to a people are the Kurkh stele (now in the British Museum: BM 118884) that mentions Ahab as an Israelite, and the Mesha stele (now in the Louvre: A05066). Both are references to the "Northern Kingdom"; from a biblical perspective this could be linked with "the ten tribes"; Hallo and Younger, Context of Scripture, 2:261-64; 2:137-38. Israel Finkelstein, in a 2019 publication, takes the mid-9th century occurrences as a starting point; despite this evidence for Israel as a name of the "Northern Kingdom," he does not reach a clear conclusion about the continuity of the name with earlier polities (since $1100 \mathrm{BCE}$ ) or possibly the name as mentioned in the Merenptah stele; Israel Finkelstein, “First Israel, Core Israel, United (Northern) Israel," NEA 82 (2019): 815; cf. Israel Finkelstein, The Forgotten Kingdom: The Archaeology and History of Northern Israel (Atlanta: Society of Biblical Literature, 2013), 74-75. In the present context it should be noted, however, that according to Finkelstein Hazor is the most northern city of this "Israel," so not including Dan and Abel. It is not possible to identify such an "Israel" as a Hebrew speaking group of people that venerates Yahweh.

${ }^{36}$ This would require preliminary work on culture, ethnicity, the possible connection of the two, as well as labels; cf., e.g., Izaak J. de Hulster, "Ethnicity and 'the Myth of the Reborn Nation': Investigations in Collective Identity, Monotheism and the Use of Figurines in Yehud during the Achaemenid Period," Approaching Religion 4 (2014): 16-24. 
question of a specific Israelite Iron Age material culture in northern Galilee. Publications by Thareani and de Hulster ${ }^{37}$ are among the latest assessments of Iron Age culture(s) north of Hula Lake (known today as Hula Valley). It is not possible to distinguish here an Israelite culture, nor is there evidence for a distinctive Aramaean material culture. Both acknowledge northern influence and, given the excavated finds she focuses on, Thareani underlines the local element of the material culture (in her case at Dan). ${ }^{38}$ The material culture north of Hula Lake seems to have been fairly unified during Iron Age I and II. This could be taken as evidence for a predominantly "Israelite" inhabitation of the area, a population that finds continuation in the inhabitants of the Iron Age II "Northern Kingdom."39 This would fit the stories of the rivalry between Israel and Aram-Damascus in 2 Sam 8 and passim in 1 Kings. This may also fit Josh 13:13's statement that the Geshurites and Maacathites lived among the Israelites—or, the Israelites among them. We hardly need to add that this observation in no way proves that the aforementioned stories in the Bible are historically true; however, the findings enhance the historical plausibility of the setting of Sheba's revolt. An author living in or aware of the Iron Age I and early Iron Age IIa surroundings north of Hula Lake would have been able to depict the setting for the story easily. Moreover, this text is a witness of a tradition or memory that took Abel-bethmaacah as an Israelite town.

Thus, from the end of the Late Bronze Age to the Iron Age IIa, Abel seems to have gained in regional significance over Dan. Abel was apparently abandoned at the end of Iron IIa, while the subsequent Iron Age IIb saw a revival of Dan. ${ }^{40}$ This leads to several

\footnotetext{
37 Izaak J. de Hulster, "Material Aramaeisms? Sphragistic Reflections on the Aram-Israel Border Zone through a Case Study on Hazor," in In Search for Aram and Israel, 229-50; Thareani, "Enemy," $169-97$. 38 Cf. de Hulster, “Material Aramaeisms," and Thareani, “Enemy,” 185.

39 The most recently published piece of evidence is a 9th century inscription from Abel-beth-maacah in Hebrew identifying Benya(h) $u$, someone with a yahwistic name, as the owner of a wine jar; Ariel David, "Hebrew Inscription on a 3,000-year-old Jar Could Redraw Borders of Ancient Israel," Haaretz January 12, 2020, https://www.haaretz.com/archaeology/.premium.MAGAZINE-hebrew-inscription-on-a-3-000year-old-jar-could-redraw-borders-of-ancient-israel-1.8376971.

40 This formulation follows Arie, "Reconsidering the Iron Age II Strata at Tel Dan"; this does not contradict the inconclusive observations by Biran (as elaborated by Alanne, "Tel Dan," esp. 47; cf. Biran, "Dan: An Update," 1688) and largely corresponds with David Ilan's take in his "Dan" (2013); and Kaniewski et al., “Climate Change,” esp. figure 3B, and Kaniewski et al., “Supplementary Materials,” esp. table S2.
} 
possible competing scenarios depending on the historical surroundings around the proverb, the revolt, and the original and revised forms of the story:

- If the Sheba story stems from-or depicts-late Iron Age I (or rather Early Iron Age II) surroundings, Abel would have been the most notable city in the area and a likely place to feature the proverb cited by the wise woman. In that scenario, the later rise of Dan from the 9th century onwards would have prompted a copyist or redactor of the story to introduce Dan in the proverb.

- Alternatively, if the story is somewhat later, Dan would have been a prominent city and part of the original story.

- It is possible that the story, or its historical kernel, was written down during a period in which Dan was significant and Abel was remembered as the origin of the story, for which reason Dan would have been added into an earlier written version. Such a model fits the eighth century, a time commonly mentioned for writing down the story. ${ }^{41}$

- Alternatively, if it was written down during a later period, in which Abel might have been more important than Dan (e.g., the Achaemenid period), Dan would have been added during a time that it had gained significance again. ${ }^{42}$

- Because the wise woman from Abel uses a proverb in which both Abel and Dan are mentioned, it is possible that the proverb stems from an earlier period, earlier in the Iron Age I or before, during which both cities were prominent.

\subsection{Oracle}

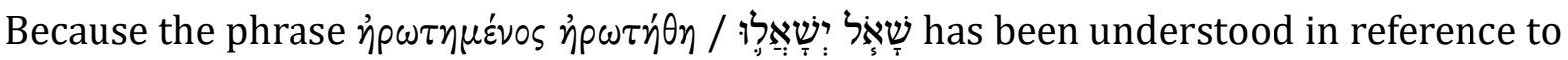
an oracle and also the wise woman herself has been understood in relation to an oracle, ${ }^{43}$

\footnotetext{
41 See the arguments in Sergi, "The United Monarchy," 340.

42 Likewise, one could search for reasons to drop Dan while rewriting the text, e.g., in relation to its importance or-speculatively - in light of condemning its cultic importance (in practice or in memory); cf. Gordon, "The Variable Wisdom of Abel”, quoted above; see also §4 below.

43 Na'aman, "Source and Composition," 347-51; cf. Panitz-Cohen and Yahalom-Mack, "The Wise Woman." Moreover, whereas most male scholars understand the phrase "a mother and a city" like the LXX as "metropolis" or in other ways as a city, most female scholars understand "a mother in Israel" as denoting a prophetess or the main representative of oracle practice. Among the male authors, e.g.: August Klostermann, Die Bücher Samuelis und der Könige (Nördlingen: Beck, 1887), 233; Otto Thenius, Die
} 
we have to address the historical question: Is there any material evidence for the existence of an "oracle" in either of the cities? The wise woman's proverb, whether in the MT or the Septuagint Vorlage, could imply there was an oracle in Abel, and possibly in Dan, whom the Israelites would consult. In the Abel excavations, evidence of cultic prominence has been found in three occupation strata of Area A: a cultic building with masseboth, large standing stones interpreted as cultic from the early to middle of the 11th century; a cultic space with a unique drainage installation, an offering table, stelae, mortars and a cult stand dated to the late 11 th and early 10th century; and a jar containing 406 astragali (animal knucklebones) of sheep goats and deer dated to the late 10th or early 9th century. ${ }^{44}$ Likewise, several finds at Dan might relate to cultic and divinatory activity. For instance, the so-called "snake house," a remarkable vessel with a "window,"45 could be linked with an oracle. ${ }^{46}$ It is unclear, however, what is needed to conclude the existence of an oracle. Does an oracle require a large sanctuary? Or, could there be an oracle that left

Bücher Samuels, Kurzgefaßtes exegetisches Handbuch zum Alten Testament 4 (Leipzig: Hirzel, 1898), 192-93; Smith, Books of Samuel, 371; P.A.H. de Boer, "The Counsellor," in Wisdom in Israel and in the Ancient Near East, ed. Martin Noth and D. Winton Thomas, VTSup 3 (Leiden: Brill, 1955), 60; A.A. Anderson, 2 Samuel, WBC 11 (Waco, TX: Word Books, 1989), 241; Georg Hentschel, 2 Samuel, NEchtB 34 (Würzburg: Echter, 1994), 89; André Caquot and Philippe de Robert, Les livres de Samuel, CAT 6 (Neuchatel: Delachaux \& Niestle, 1997), 571; Shimon Bar-Efrat, Das zweite Buch Samuel: Ein narratologisch-philologischer Kommentar, BWANT 181 (Stuttgart: Kohlhammer, 2006), 210; and ErnstAxel Knauf, Richter, ZBK 7 (Zurich: TVZ, 2016), 75. Among the female authors: Marcia L. Geyer, "Stopping the Juggernaut: A Close Reading of 2 Samuel 20:13-22," USQR 41 (1986): 38; Irmtraud Fischer, Gotteslehrerinnen: weise Frauen und Frau Weisheit im Alten Testament (Stuttgart: Kohlhammer, 2006), 59; Shawna R. B. Atteberry, What You Didn't Learn in Sunday School: Women Who Didn't Shut Up and Sit Down (Eugene, OR: Resource, 2013), 9. Andrew Steinmann, 2 Samuel, Concordia Commentary (St. Louis: Concordia, 2017), 391, takes the word 'mother' as a "double entendre." In comparison with Judges 5:9, "a mother in Israel" may well be a wise woman or a "prophetess." Some might speak in this context of an "oracle" (cf. Yahalom-Mack, Panitz-Cohen and Mullins, “From a Fortified Canaanite City-State," 145); although this term is possibly infelicitous, we have adopted this pithy concept to name our subtitle and to phrase its leading question.

44 Panitz-Cohen and Yahalom-Mack, "The Wise Woman," esp. 33. Astragali were widely used in antiquity for games but also for divinatory practices.

45 The vessel is called a "snake house" because vessels of similar shape had terracotta snakes attached to them; see also for references Biran, Biblical Dan, 152-53; and Alanne, "Tel Dan," 58.

46 Wolfgang Zwickel, "Dan," Wibilex: Das wissenschaftliche Bibellexikon im Internet, https://www.bibelwissenschaft.de/stichwort/16185. 
no trace in the archaeological record at all-only the woman, perhaps with persons in her lineage, representing the oracle? Whereas one could take the existence of certain objects to enhance the historical plausibility of both Abel and Dan as places for an oracle, the material remains are not specific enough.

\subsection{The Motif of Women on City Walls in Iconography and Literature}

While the narrative references entities, such as Abel-beth-maacah, that can be the object of historical and archaeological research, the narrative does not necessarily need to be based on a specific event. Therefore, we investigate the possibilities of traditions and motifs that might have influenced the way the text has been shaped.

Women on city walls are featured in two other stories in the Bible: the mother of the cooked son in 2 Kgs 6:26-29, and the woman with the mill stone that killed Abimelech in Judg 9:53. These examples in narrative setting (notably all three war stories) are reminiscent of the wise woman at the gate in Prov 1:20-21 and 8:2-3. In addition, scholars have compared the wise woman in 2 Sam 20 with the wise woman of Tekoa (2 Sam 14); such a comparison can lead to an argument about the one story being dependant on the other, ${ }^{47}$ calling into question the historical singularity of the narrated event.

The motif of a woman on a wall also appears in visual art. Silvia Schroer, having studied 2 Sam 20 in various contexts, published an article in which she presents 9 th century reliefs of Asshurnasirpal II and scenes on the bronze Balawat Gates of his son Shalmaneser III. These images feature women on walls in times of war, but unlike 2 Sam 20, these women are lamenting, wailing or mourning. ${ }^{48}$ Considering a possible influence from a motif, one needs to consider that a motif can be turned upside down: a wise woman on the wall is the antitype of weeping women on the wall.

\footnotetext{
47 E.g., Jan Wim Wesselius, “De wijze vrouwen in 2 Samuël 14 en 20,” NedTT45 (1991): 89-100; Claudia V. Camp, “The Wise Women of 2 Samuel: A Role Model for Women in Early Israel?," CBQ 43 (1981): 14-29; and Larry L. Lyke, King David with the Wise Woman of Tekoa: The Resonance of Tradition in Parabolic Narrative, JSOTSup 255 (Sheffield: Sheffield Academic, 1997), 165-68.

48 The reliefs and the gates are now in the British Museum, where they can be found as BM 124554 and BM 124683. See Silvia Schroer, "Die weise Frau auf der Stadtmauer von Abel-bet-Maacha (2Sam 20,14-22)," in Seitenblicke: Literarische und historische Studien zu Nebenfiguren im zweiten Samuelbuch, OBO 249 (Göttingen: Vandenhoeck \& Ruprecht, 2011), 394-411. Schroer had erroneously identified a figure as a woman throwing a stone but corrected this in a later publication; see Silvia Schroer, "No Woman on the City Wall of Hamanu: A Note of Correction," Lectio Difficilior 1 (2018), http://www.lectio.unibe.ch/18_1/schroer_silvia_no_woman_on_the_city_wall_of_hamann.html.
} 


\section{Conclusion: "Abel" or "Abel and Dan"?}

Does the preceding discussion allow us to choose between the text-forms "Abel" in the MT and "Abel and Dan" in the putative base text of the Septuagint? From a text-critical point of view, the latter should perhaps be preferred:

- The variant text-forms שאל ישאלו באבל וכן התמו אנכי שלמי אמוני ישראל (MT) and שאל ישאלו באבל ובדן התמו אשר שמו אמוני ישראל (LXX base text) are graphically quite close to each other which suggests that the variation was brought about by a series of graphical mistakes, possibly due to material damage in an archetype.

- In particular, the confusion between the MT וכן and the reconstructed ובדן* very likely results from a graphical mistake. That the direction was from ובדן to וכן to suggested by the latter being a much more common word.49 Then again, "Abel" may have caused a scribe to think of a nearby geographical name which caused the reading error from ובדן to*.

- When variation is brought about by conscious revising, the secondary text is bound to be smoother or, at least, less difficult. However, when the variation is due to transcriptional issues, one may expect the secondary form to be grammatically more difficult, as the MT form clearly is here.

Archaeology suggests Abel as a plausible place for the setting of the story, while not suggesting Dan to be a completely unsuitable place (an oracle can work in a small place). ${ }^{50}$ The later diminishing in importance of Abel and the rise of Dan makes it plausible that Dan could have been introduced in the story by a reviser or, at least, a creative copyist.

\footnotetext{
49 In the Hebrew Bible, דן occurs 65 times and כן occurs 750 times; in the historical books, specifically, דן occurs 39 times and כן occurs 163 times.

50 Note with Panitz-Cohen and Yahalom-Mack, "The Wise Woman," 31, that wise women (as local traditions) mainly play a role in the pre- and early monarchic period at the periphery. Interestingly, they seem to have read Na'aman's article, writing: “Although our Wise Woman herself was not necessarily a divinator or spiritual leader, tradition places her in a town-and a nearby region, if we add Dan, as the Septuagint and the archaeological evidence do-characterized as having a long reputation for wisdom and faithfulness to the tradition of Israel"; "The Wise Woman," 33; they do not make a clear argument for Dan, apparently following Na'aman's 8th century date.
} 
Such a change could have been partly prompted by bad copying conditions: וכן, or a garbled version of it, would be more likely to be read as ובדן if Dan was considered a prominent place by the copyist. This suggestion is in diametrical opposition to the one by Gordon, who would allow for "the possibility that the absence of Dan from the MT has a polemical explanation," namely, that the name Dan was omitted because of it being associated with idolatry in $1 \mathrm{Kgs} 12$ and $2 \mathrm{Kgs} 10$. If the proverb is interpreted as making a juxtaposition-good advice in Abel, bad in Dan-the name "Dan" could have been added precisely in order to polemicize against it.

As for archaeological evidence, we must consider various historical situations that contribute to the story. The proverb (assuming its authenticity) is supposed to be the first layer present in the story. There being no evidence from the Bronze Age to confirm or to deny the possibility of oracles and their traditions (which would have grown, in the end, into a proverb) at Abel or Dan during this period. For those who relate cultic evidence with the probability of an oracle, we can point out that the record of Abel testifies cultic activity during most of the Iron Age I.

The second historical situation is the end of the Iron Age I or rather the beginning of the Iron Age IIa, the setting of the story. At this time, Abel was an important city, whereas Dan was insignificant. This situation changed during the Iron Age II. Most scholars date the story to the eighth century. Beyond the textual evidence, archaeological evidence of motifs employed in the narrative testify to changes in the story; siege warfare, for example, would have made its appearance in Israel/Palestine only in the ninth or late eighth century.

In this paper, we combined various considerations to shed light on a textual problem:

- Textual criticism of the Septuagint, including translation technique

- Transcriptional probability in the Hebrew square script

- Hebrew syntax

- The possibility of revision due to religious or political polemics

- Archaeological findings in Iron Age Abel and Dan

- Historical plausibility of fortifications, siege warfare, women on walls, and existence of an oracle in Abel and Dan

- The literary and iconographic motifs of a wise woman and of a woman on the city wall from a tradition-historical point of view 
Our primary aim was to map the various historical and text-historical possibilities. Although we have taken into account considerably more archaeological information than previous studies, the material does not allow for one clear conclusion concerning the date of the first composition (nor about when Dan would have been added or dropped for conscious reasons or by scribal mistake). We have tried to elucidate-even if only to a small extent-the complexities involved in the narrative of 2 Sam 20. The data presented here underline the variety of elements present in the narrative and the growth of the story, and the caution and courage required to tackle texts like 2 Sam 20. 